\title{
The use of gamification to teach in the nursing field
}

\author{
Uso de gamificação para o ensino de informática em enfermagem \\ Uso de gamificación en la enseñanza de la informática en enfermería
}

\author{
Talita Candida Castro', Luciana Schleder Gonçalves' \\ ' Universidade Federal do Paraná. Curitiba, Paraná, Brazil.
}

How to cite this article:

Castro TC, Gonçalves LS. The use of gamification to teach in the nursing field.

Rev Bras Enferm [Internet]. 2018;71(3):1038-45. DOI: http://dx.doi.org/10.1590/0034-7167-2017-0023

\author{
Submission: 03-19-2017_Approval: 06-03-2017
}

\begin{abstract}
Objectives: To investigate whether the course offer with elements of gamification contributes to the formation of competences in Informatics in Nursing; and evaluate it based on teaching and learning criteria and content structure. Method: Exploratory, applied and technological innovation research, with a qualitative and quantitative approach, developed at a university in the southern region of the country between February and November 2016. Participants were professors (5) and nursing students (10). Results: The adoption of gamification was considered an interesting and innovative approach, as an alternative to traditional practices and applicable to Nursing teaching. In the quantitative analysis, it was observed that the course contemplates the set of evaluated criteria. Final considerations: Gamification contributes to the formation of competences among Nursing students for positively influencing the teaching-learning process. It can be understood as one more resource in the teaching work with a view to student motivation and meaningful learning.

Descriptors: Informatics in Nursing; Educational Technology; Teaching; Computer Knowledge; Competency Based Education.
\end{abstract}

\section{RESUMO}

Objetivos: Investigar se a oferta de curso com elementos de gamificação contribui para a formação de competências em Informática em Enfermagem; e avaliá-lo a partir de critérios de ensino e aprendizagem e de estrutura do conteúdo. Método: Pesquisa exploratória, aplicada e de inovação tecnológica, de abordagem qualitativa e quantitativa, desenvolvida em uma universidade da Região Sul do país entre fevereiro a novembro de 2016. Participaram docentes (5) e estudantes de enfermagem (10). Resultados: A adoção de gamificação foi considerada uma abordagem interessante e inovadora, como alternativa às práticas tradicionais e aplicável ao ensino de Enfermagem. Na análise quantitativa, observou-se que o curso contempla o conjunto de critérios avaliados. Considerações finais: A gamificação contribui para a formação de competências entre estudantes de Enfermagem por influenciar positivamente o processo de ensino-aprendizagem. Ela pode ser compreendida como mais um recurso no trabalho docente com vistas à motivação dos estudantes e à aprendizagem significativa.

Descritores: Informática em Enfermagem; Tecnologia Educacional; Ensino; Conhecimentos em Informática; Educação Baseada em Competências.

\section{RESUMEN}

Objetivos: Investigar si la oferta de curso con elementos de gamificación contribuye a la formación de competencias en Informática en Enfermería; y evaluarlo a partir de criterios de enseñanza y aprendizaje y de estructura del contenido. Método: Investigación exploratoria, aplicada y de innovación tecnológica, de abordaje cualitativo y cuantitativo, desarrollada en una universidad de la Región Sur del país entre febrero y noviembre de 2016. Participaron docentes (5) y estudiantes de enfermería (10). Resultados: La adopción de gamificación fue considerada un abordaje interesante e innovadora, como alternativa a las prácticas tradicionales y aplicable a la enseñanza de Enfermería. En el análisis cuantitativo, se observó que el curso contempla el conjunto de criterios evaluados. Consideraciones finales: La gamificación contribuye para la formación de competencias entre estudiantes de Enfermería pues influye positivamente el proceso de enseñanza-aprendizaje. La gamificación puede ser entendida como un recurso adicional al trabajo docente que se destina a motivar los estudiantes y el aprendizaje significativo. Descriptores: Informática en Enfermería; Tecnología Educativa; Enseñanza; Conocimientos en Informática; Educación Basada en Competencias. 


\section{INTRODUCTION}

Information and Communication Technologies (ICTs) have impacted the work process in Health and Nursing, raising the need for prior preparation of Health professionals for their use in the various scenarios of professional practice. Thus, a current concern is the qualification of professionals as a way to ensure that their knowledge and skills are in line with the new paradigms of health care, specifically on the themes related to the insertion of ICTs. The National Curricular Guidelines (DCNs) for Nursing undergraduate courses point out, from the perspective of skills and abilities related to communication, that nurses are in charge of mastering these ICTs. Thus, aspects such as the development of knowledge, skills and attitudes regarding the use of information technology in professional practice need to compose the list of desirable competencies of nurses ${ }^{(1-3)}$.

In parallel, ICTs have also influenced educational practices in general, interfering with how subjects relate, learn and teach $^{(4-6)}$. It is a fact: initiatives that analyze the development and adoption of strategies involving ICTs and educational technologies in Nursing teaching have grown and their results have been promising ${ }^{(7)}$.

In the same scenario, discussions related to online learning have matured over the years. This modality, which includes the use of web-based platforms, has the potential to support learning by facilitating access and the possibility of flexible scheduling ${ }^{(8-9)}$. In addition, the use of games and elements of gamification in pedagogical strategies has been adopted with the intention of motivating and involving students, as a way of also favoring learning ${ }^{(8,10-11)}$.

Gambling uses gaming elements (such as its aesthetics, mechanics and dynamics) in non-gaming contexts to create a differentiated experience that meets human needs and motivations ${ }^{(11-14)}$. Several initiatives for the application and analysis of gamification in teaching can be identified in the Brazilian context ${ }^{(11,15-18)}$, and it is possible to affirm that this is an innovative strategy which has gained space in the educational field, which justifies the idea of to apply it to nursing education.

In this sense, considering the potential of the use of ICTs and elements of gamification in educational strategies, as well as the need for actions that contribute to the development of computer skills in the area of Nursing, the following guiding question was formulated that led to the development of this research: How to contribute to the development of computer skills among undergraduate students in Nursing using ICTs?

This article describes, therefore, the experience of building a course in a Virtual Learning Environment (VLE) with elements of gamification, for the teaching of Health Informatics in Nursing for undergraduate students in Nursing.

\section{OBJECTIVE}

To do so, its objectives were to investigate whether the offer of course with use of gamification contributes to the formation of competences in Computer Science in Nursing; and to evaluate the course based on teaching and learning criteria and content structure, in the perception of Nursing students and professors.

\section{METHOD}

\section{Ethical aspects}

The research complies with the ethical precepts of Resolution 466/12 $2^{(19)}$ of the Brazilian National Health Council (NHC) and was approved by the Research Ethics Committee (REC) of the Health Sciences Sector of the Federal University of Paraná (UFPR). The anonymity of the research participants was guaranteed by their identification by codes in the description of the qualitative results, being $\mathrm{S}$ for students and $\mathrm{P}$ for the professors, which were randomly enumerated.

\section{Design, place and period of study}

It is an exploratory, applied, technological innovation, qualitative and quantitative approach to the analysis of the data obtained in its different phases. The research scenario was the undergraduate course in Nursing at UFPR. The research was developed between February and November 2016.

\section{Research participants and inclusion and exclusion criteria}

The research participants were ten students $(S)$ and five professors $(\mathrm{P})$ of the undergraduate nursing course, who were randomly enumerated (students from S1 to S10 and professors from P1 to P5). The inclusion criteria of the participating students included, besides the formalized acceptance to participate in the research by signing the Free and Clarified Consent Term (FCCT), to be a graduate student in Nursing of the eighth period and to have completed the discipline of Planning and Administration in Health The requirement was to belong to the Health Planning and Administration area of the UFPR Nursing Department or to be a member of UFPR's Technology and Innovation in Health Research Group (TIS). The exclusion criteria were: students and Nursing professors who did not access the course or did not complete their evaluation by completing the data collection instrument.

Twenty-four students were invited to participate in the study, of which 12 signaled the acceptance by signing the FCCT, and received log in access to the course. Of these, ten completed the assessment by responding to the online instrument, which corresponded to a sample of $46.66 \%$ of the total number of students enrolled in the Health Planning and Administration discipline. For the second group, ten professors were invited to participate of the survey and all accepted, receiving access log in; of these, five completed the assessment, corresponding to a sample of $50 \%$ of the total number of invited professors. Thus, at the end of the data collection period, the sample consisted of 15 participants.

\section{Methodological procedures}

It is important to point out that the present report refers to the stages of development and evaluation of a course in a VLE using gamification elements. The procedures carried out in the planning phase - the process of elaboration of the educational objectives and the proposal of programmatic content based on competences in the field of informatics in Nursing aimed at the newly formed nurse - have already been published recently (20).

Thus, the development phase included: a) the production of instructional content about Health Informatics and Nursing from 
a bibliographical review of the literature, with a later synthesis of the findings and elaboration of didactic material; b) the choice of gamification elements adopted; c) the diagramming of the material produced in the Moodle platform (Modular Object Oriented Dynamic Learning Environment) in version 3.1, and; d) completion of the course and the development of tests. The diagramming and development of tests in Moodle counted on the technical support of members of the Group of Research in Science, Information and Technology (GP-CIT) of UFPR.

On the other hand, the assessment phase included the evaluation of the course, based on the application of the "Ergodesign Evaluation Tool in Didactic Material" by Kuntz (2007)(21), which was adapted for the research and made available on-line from the use of the SurveyMonkey tool. This instrument evaluates essential aspects of design and ergonomics to promote self-learning and presents two different sets of criteria, ten of them related to Teaching and Learning and six to Content Structure. Each criterion was evaluated from a Likert scale $(1,2,3,4,5)$, considering 1 for the existence of the criterion in the course and 5 for its non-existence. In addition, an open question was inserted in which the participants of the research should comment on their experience with this proposal of using Moodle with elements of gamification. A minimum access time of two hours and an average time of 15 minutes for filling the instrument was provided.

\section{Data analysis}

In the quantitative approach, data analysis was performed using simple descriptive statistics using Microsoft Excel ${ }^{\circledR}$ software. In the qualitative approach, a content analysis ${ }^{(22)}$ was made based on the reading of all participants' responses, their division into units of records, categorization and, finally, empirical analysis of the categories that rely on snippets of responses.

\section{RESULTS}

The development phase included a bibliographical review, production of the instructional content and its suitability for the Distance Learning modality (EAD). Different resources were developed for the course, including texts, illustrations and videos, as well as reading suggestions were selected for each topic covered. The content was distributed in four modules in the course, namely: 1) Basic Concepts of Informatics in Health and Nursing; 2) The Strategic Use of Information; 3) Health Information Systems (SIS); and 4) Applications of Informatics in the Work of the Nursing Professional.

Throughout these modules, activities such as case studies, multiple choice exercises with automatic feedback or error correction, participation in forums, conducting research to be posted and resolution of exercises in game format such as quizventure plugin and crossword and forca activities (Chart 1).

Chart 1 - Exercises in game format, Curitiba, Paraná, Brazil, 2017

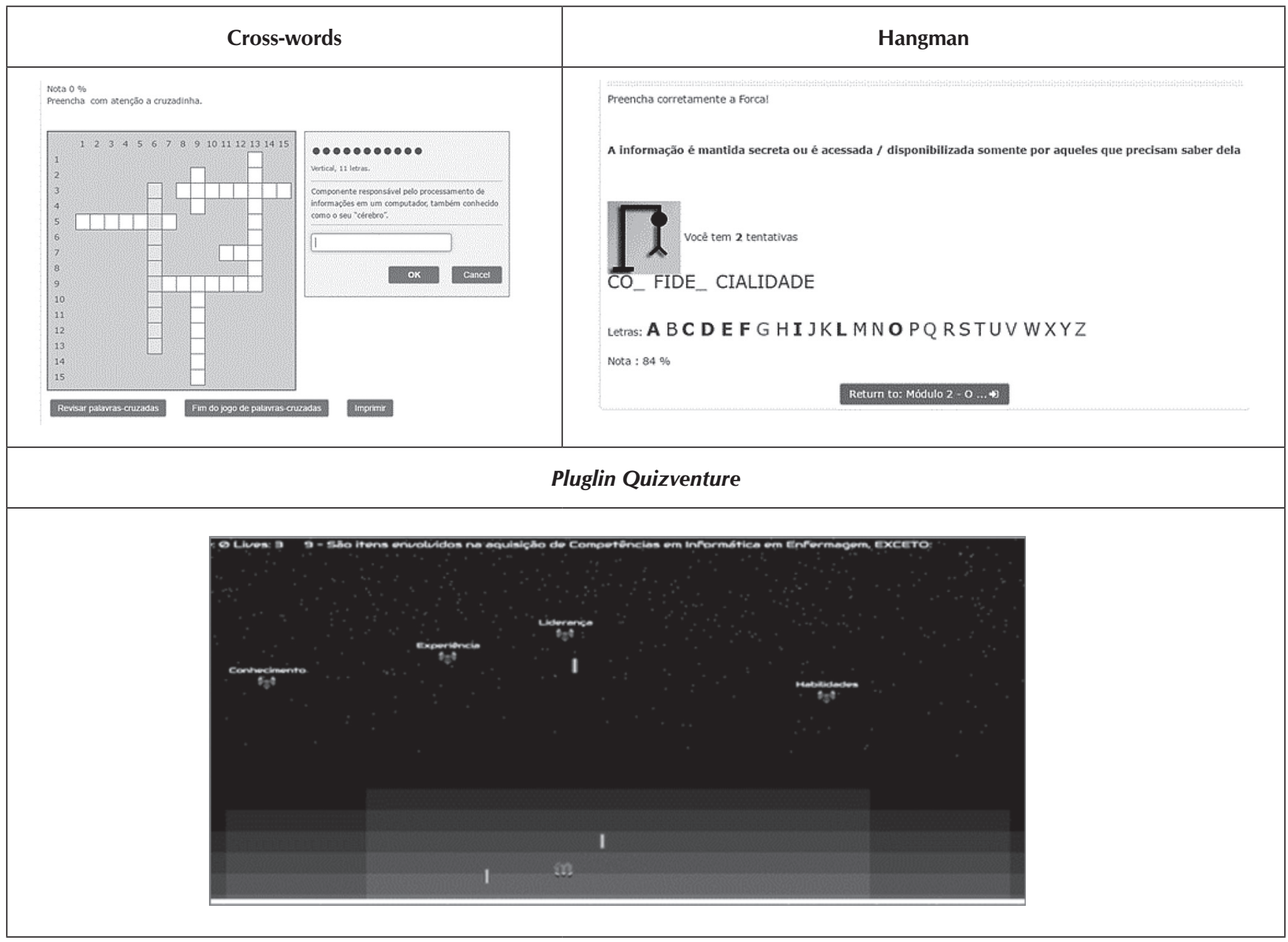


Chart 2 - Gamification elements applied to the course, Curitiba, Paraná, Brazil, 2017

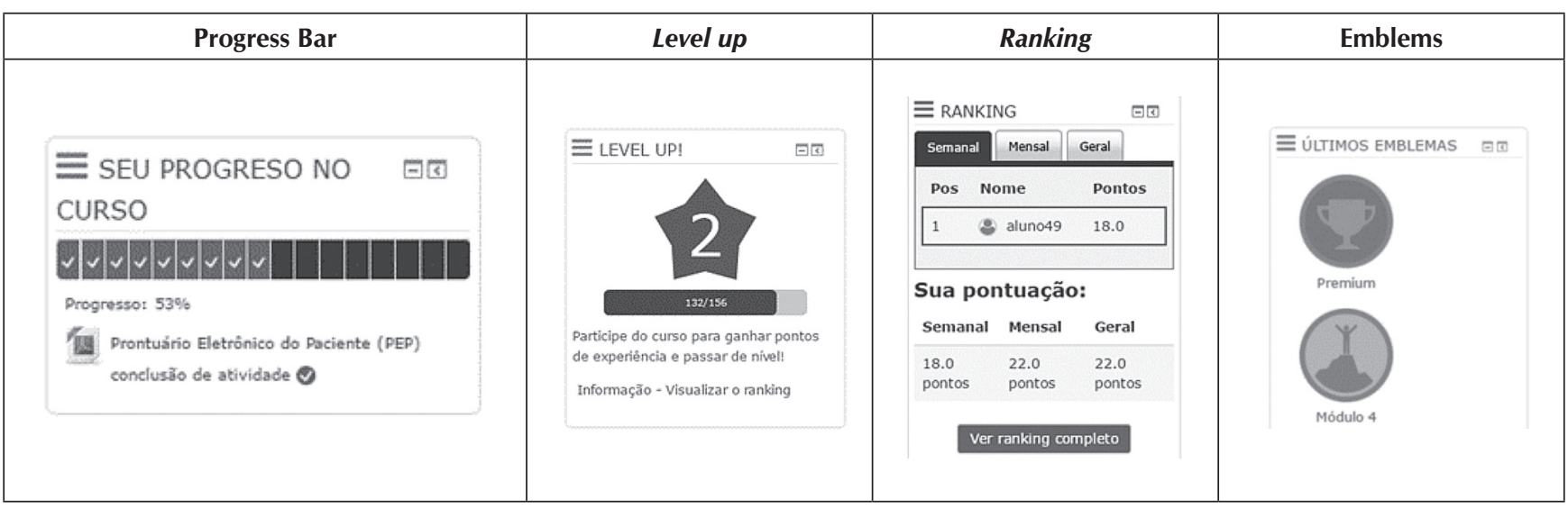

Because playing can stimulate and motivate students to be victorious, but losing is generally not enjoyable, it was considered important to give students the opportunity to play again in the search for the correct answer, so that frustration would be replaced by the idea that victory is possible and, above all, for the student learner to have the opportunity to reflect on content that needs reinforcement on their part. Thus, students were able to redo the cross, the gallows, the final plugin quizventure, in short, all the exercises in game format (Chart 1) as many times as necessary, in search of the correct answer and, above all, the consolidation of knowledge.

In cross-border activity, with each new attempt its conformation was modified, but without changing the questions. Already the activity of gallows was fed by a bank of questions on the subjects worked in the module in which it was inserted. In the quizventure plugin, the student had access to multiple choice questions. In order to make it operational, a problem bank was elaborated with contents worked along the four modules of the course. The logic of the game consisted of commanding the ship to shoot the correct option, among those presented at the top of the screen. At the same time, the player should deflect the shots of the other ships, avoiding being hit. In the upper left corner of the screen, the student could track how many "lives" he possessed, as well as his score in the game.

Chart 2 presents the gamification elements applied to the Moodle Platform, including progress bar, badges, ranking and level up.

The progress bar was diagrammed in the main course interface to provide an overview of the student's performance against their ultimate goal, which was to complete all of the proposed readings and activities. This item shows the steps performed and those that still need to be studied, when passing the cursor in each of the rectangles of the bar.

The level up was adopted in order to allow the visualization of the progress of the student according to their experience and interaction with the course. This plugin provides level crossing over the player's student participation in course activities and gaining experience points. Its main objective is to stimulate the continuity of studies and the participation of the proposed activities. In addition to the level up, the ranking was adopted as a second general scoring model. This plugin, which was also inserted in the main interface, presents the first places of the course, considering its participation in the proposed activities, being able to generate a general, weekly and monthly ranking.

The emblems were adopted in order to reward students by completing the modules. Throughout the course, five emblems were inserted, four associated to the completion of each of the modules and a bonus associated to the accomplishment of all the proposed activities. At each stage, the student player is notified by message about his/her new achievement, and the emblem is visible in his/her profile, and can be seen by other participants of the course.

With respect to the results from the evaluation phase, it was possible to observe a higher concentration of answers for note 1 (the existence of the criteria evaluated in the course) and the absence of answers for the two groups (students and nursing professors) note 5 (nonexistence), both in terms of Teaching and Learning and Content Structure (Table 1).

The author ${ }^{(21)}$ of the instrument used recommends that the percentage of $70 \%$ be used as the satisfaction index for the evaluated criteria, and that percentages lower than this index would indicate the need to consider possible improvements.

Thus, it was verified that most of the criteria reached the satisfaction index, suggesting that, in general, all were included in the developed course. As an exception, students are evaluated for criterion 5 (There are exercises that develop the practical activity, $40 \%$ for grade 1 and $40 \%$ for 2 refer to the existing criterion), and criterion 6 (Difficulty and density of the content are acceptable, $50 \%$ for grade 1 and $40 \%$ for grade 2 refer to the existing criterion), which differ from professors' assessments (100\% and $89 \%$ for grade 1 , respectively).

At the end of the questionnaire, the participants were invited to comment on the experience with the proposal of using Moodle with elements of gamification. From the analysis of the content of the responses of the two groups, six distinct categories emerged: suggestions; praise; weaknesses; notification of errors; content structure in VLE; and teaching and learning. The following are examples of excerpts from participants' responses, which are related in each of the categories identified. 
Table 1 - Evaluation of the Course by Nursing Students and Professors ( $N=15)$, Curitiba, Paraná, Brazil, 2017

\begin{tabular}{|c|c|c|c|c|c|c|c|c|c|c|}
\hline & \multicolumn{5}{|c|}{ Professors $(n=5)$} & \multicolumn{5}{|c|}{ Students $(n=10)$} \\
\hline & 1 & 2 & 3 & 4 & 5 & 1 & 2 & 3 & 4 & 5 \\
\hline Teaching and Learning Criteria & & & & & & $\%(n)$ & & & & \\
\hline 1 - All information available is necessary. & $100(5)$ & 0 & 0 & 0 & 0 & $70(7)$ & $30(3)$ & 0 & 0 & 0 \\
\hline 2 - Make content drills available. & $100(5)$ & 0 & 0 & 0 & 0 & $80(8)$ & $10(1)$ & 0 & $10(1)$ & 0 \\
\hline 3 - There are exercises in order to promote reasoning. & $100(5)$ & 0 & 0 & 0 & 0 & $80(8)$ & $10(1)$ & 0 & $10(1)$ & 0 \\
\hline 4 - There are activitives in order to promote associations and interpretations. & $100(5)$ & 0 & 0 & 0 & 0 & $80(8)$ & 0 & $10(1)$ & $10(1)$ & 0 \\
\hline 5 - There are exercises that develop practive activity. & $100(5)$ & 0 & 0 & 0 & 0 & $40(4)$ & $40(4)$ & $10(1)$ & $10(1)$ & 0 \\
\hline 6 - The content's difficulty and density is acceptable. & $80(4)$ & $20(1)$ & 0 & 0 & 0 & $50(5)$ & $40(4)$ & 0 & $10(1)$ & 0 \\
\hline 7 - Make diversified resources available such as graphics, tables, figures. & $100(5)$ & 0 & 0 & 0 & 0 & $70(7)$ & $30(3)$ & 0 & 0 & 0 \\
\hline $\begin{array}{l}8 \text { - The material is adapted to its audience, not depending on unnecessary } \\
\text { energy and strenuous efforts. }\end{array}$ & $80(4)$ & 0 & $20(1)$ & 0 & 0 & $70(7)$ & $30(3)$ & 0 & 0 & 0 \\
\hline $\begin{array}{l}9 \text { - There are explanatory demonstrations like in bubbles, monitoring tasks, } \\
\text { showing steps to be followed }\end{array}$ & $100(5)$ & 0 & 0 & 0 & 0 & $80(8)$ & $10(1)$ & $10(1)$ & 0 & 0 \\
\hline 10 - Generally the information is clear and transparent. & $100(5)$ & 0 & 0 & 0 & 0 & $90(9)$ & $10(1)$ & 0 & 0 & 0 \\
\hline Content Study Criteria & & & & & & $\%(n)$ & & & & \\
\hline 11 - The content is divided in order to make the learning process easier. & $100(5)$ & 0 & 0 & 0 & 0 & $100(10)$ & 0 & 0 & 0 & 0 \\
\hline 12 - In the content's writing process, it is followed a clear logic. & $80(4)$ & $20(1)$ & 0 & 0 & 0 & $100(10)$ & 0 & 0 & 0 & 0 \\
\hline 13 - Graphic elements are easily identified. & $100(5)$ & 0 & 0 & 0 & 0 & $80(8)$ & $20(2)$ & 0 & 0 & 0 \\
\hline 14 - Vocabulary is suitable for the target audience. & $80(4)$ & $20(1)$ & 0 & 0 & 0 & $80(8)$ & $20(2)$ & 0 & 0 & 0 \\
\hline 15 - Titles are according to what they represent. & $100(5)$ & 0 & 0 & 0 & 0 & $90(9)$ & 0 & $10(1)$ & 0 & 0 \\
\hline 16 - The essential points in the content are highlighted. & $80(4)$ & $20(1)$ & 0 & 0 & 0 & $80(8)$ & 0 & $20(2)$ & 0 & 0 \\
\hline
\end{tabular}

As for the category Suggestions, the participants expressed themselves in the following statements:

[...] quizventure requires additional explanations. It is suggested that the pdf files present a statement and the references, as well as the indication of authorship, since they are likely to be saved. (P3)

[...] on youtube, I suggest putting a description in the videos and, if possible, linking the videos to others that might interest you. (S)

As for the category Cheers, the participants stated:

I especially liked the suggested reading links. (S4)

[...] I believe the experience was very productive and fun [...] Congratulations!!! (S5)

Regarding the Fragilities category, the participants stated that:

[...] Just be careful with the icons, depending on the light and contrast settings of the monitor they are not visible. (S6)

[...] the Moodle Platform does not allow the page to return to where it was after reading. This ends up bothering us, because we always have to scroll the whole page to get where we were before. (S8)
Regarding the Error Notification category, participants said:

There are [sic] typing errors, only [...]. (S2)

Videos are repeated. (P3)

Regarding the Structure and Content category of VALE, one participant reported that:

The platform interface is very beautiful, super clean making the navigation lighter and more comfortable. (E6)

Finally, in the category Teaching and Learning, the participants expressed that:

[...] I feel less tired, contrary to what would happen in an hour and a half of lecture. (S6)

I believe that learning is fixed more appropriately when using technologies such as this platform. The games and content available are very interesting and make the students more interested in the class. (S10)

The defined evaluation strategies are adequate and the games used allow interactivity and allow the variation of evaluation methods in a relevant way. (P3)

[...] I find it provocative and will probably keep students interested. (P4) 


\section{DISCUSSION}

The need to train professionals able to meet the new and growing demands of Information Technology (IT) in Health involves planning and the greater offer of projects that encourage their training, which "requires the development of new curriculum and new didactic material, besides of new systems for the training of professors and trainers " ${ }^{(23)}$. Thus, it was tried to elaborate a didactic material that can be used by the professors in order to favor the development of competences in the scope of the informatics in Nursing among the students still in the graduation.

When analyzing the DCNs for Nursing courses and the role of competencies in the training of nurses, it is reaffirmed the relevance of this professional to present technological skills and computer skills in their practice, considering that technology is inclined to be increasingly more embedded in the various work processes in Health and Nursing. Although recognizing the challenge involved in overcoming the weaknesses, barriers and difficulties inherent to constant innovation scenarios, the insertion of active methodologies in the formal teaching-learning processes, in in-service training and in permanent education programs is pointed out as one of the possibilities to expand efforts in the face of the rigidity of traditional methods found in Nursing teaching ${ }^{(24)}$. Thus, the choice of approach to the subject in a VLE with elements of gamification arose from the need to seek new strategies for teaching in Nursing, at a time in which we discuss possibilities to transcend the traditionalism found in institutions of Higher Education ${ }^{(8-9)}$.

In a study ${ }^{(25)}$ that reported the use of the Moodle platform in a discipline of Computer Science in Nursing, it was identified that this method proved to be complementary to face-to-face teaching. The authors also reinforced that EAD represents a learning environment for the teaching of ICTs and Health Informatics contents, as it "promotes good professional practices, enabling the student to meet current market requirements, considering the rapid incorporation of resources health services "(25).

Important aspects to be considered in initiatives aimed at the use of VLE and gamification should be those of a technical and operational nature. It reinforces the need for professors to be able to count on technical support for the ICTs adopted, since, although they can be trained and encouraged to innovate in their practices, they may also encounter particular difficulties. Technical issues, which are not always predictable or solvable, can be considered as impediments to professors ${ }^{(10)}$ and, specifically, in relation to Moodle, practical training is desirable ${ }^{(25)}$.

Regarding the gamification elements applied, similarities are observed in relation to the findings of studies that investigated the gamification techniques most used in different $V L E^{(15)}$, as well as those that present the most prevalent in the areas of Education and Health ${ }^{(26)}$. It is noticed that the elements of game progression, points, feedback, ranking, levels and emblems have been commonly adopted in educational strategies ${ }^{(15,26)}$.

The criteria belonging to the Content Structure category were considered. In the qualitative analysis, there was a mention (S6) of the structure of the VLE content, which can be related to aspects of ergonomics and interface usability. In Nursing, some authors ${ }^{(27-30)}$ have already adopted criteria related to ergonomics and usability in the evaluation of technologies applied to their educational strategies, demonstrating that this type of evaluative approach can also contribute to the adequacy of such tools for teaching in Health Others ${ }^{(31)}$ emphasize the need to perform usability and quality tests.

In the evaluation of the criteria of Teaching and Learning, the findings from the qualitative analysis corroborate the results of satisfaction of the participants in relation to the evaluated criteria. They emphasize the innovative character, its positive impact on the teaching and learning process in Nursing, as well as the potential of gamification in increasing students' interest in the class or course, stimulating interactivity.

The gamification elements can support professors, mentors and mentors of ODL initiatives in the challenge of keeping students engaged and motivated; and thus can act to reduce the rates of evasion known to be present in this modality ${ }^{(5)}$. Moreover, these elements are an option for the challenges commonly encountered in ODL and VLEs, such as: students' lack of interest and lack of motivation; the competition between the activities proposed by VLEs and the multiple forms of entertainment available online; and the use of these spaces only as repositories of materials and not as an environment of collective construction and dissemination of knowledge $\mathrm{e}^{(32)}$.

The discussion of gamification as a motivational factor to reduce evasion ${ }^{(17)}$ argues that gambling environments tend to be more attractive and promote fewer drop-outs and dropouts, as well as challenge students to overcome obstacles and to complete courses. In a recent research ${ }^{(18)}$ on the perceptions of Brazilian researchers about the influence of gamification in ODL, their potential to dynamize learning, to attract and retain students' attention, and to motivate them was identified. Already as main challenges raised, the authors highlight the need for professor training and the reconciliation between the elements of gamification and the available ICTs.

The fact that a research participant reported being less tired after studying the course than in an expository class suggests that the pedagogical strategy can also be a tool for alternating traditional teaching methods. In a recent study ${ }^{(33)}$, which compared the teaching strategies of expository classroom dialogues with an educational hypermedia about peripheral venous puncture, it was verified that both had potential to achieve meaningful learning. In addition, the satisfaction of the academics regarding the hypermedia used was evidenced.

\section{Study limitations}

As limitations encountered by this study, we have the small sample number of participants of the research and the limited time for interaction and analysis of the course. However, it is expected that the experience with the application of the gamification technique in Nursing teaching will consist of an incentive for innovative practices in teaching and mediated by ICTs, under pedagogical proposals that aim at meaningful learning.

\section{Contributions for the Nursing field}

Although the results are initial and exploratory in nature, it is believed that the potential of gamification in making education more engaging and reflecting on traditional practices in Nursing teaching. 
In addition, faced with the challenge of using ICTs launched by the guiding question of this research, it is reinforced the possibility of using strategies involving VLE and its resources as a way to favor learning. The evaluation of the didactic material showed that the course developed can be applied in Nursing teaching and constitute more resource of the teaching work in front of the challenge to encourage the construction of competences in the scope of Nursing Informatics among undergraduate students.

\section{FINAL CONSIDERATIONS}

Regarding the insertion of ICTs in the teaching work and specifically on the development of strategies involving VLE, it is emphasized that in addition to volition, there must be prior training and specialized support for consulting, as well as for solving any problems technical and operational. Difficulties of this order may lead to the frustration of the professor in adopting ICTs in their practice or, furthermore, culminating in their underutilization due to the lack of knowledge of all their functionalities. In this sense, educational institutions should also provide basic structure and support.

For future applications of gamification, it is suggested that, just as in games, the professor explores different ways of increasing the levels of difficulty as the student experiences it. It is believed that, for the course developed, new experiences should consider, for example, the increase of activities in each of the Modules and the condition that these activities be gradually more challenging to the students.

\section{REFERENCES}

1. Brasil. Ministério da Educação. Conselho Nacional de Educação (CNE). Câmara de Educação Superior (CES). Resolução CNE/ CES N³, de 7 de novembro de 2001. Institui Diretrizes Curriculares Nacionais do Curso de Graduação em Enfermagem, 2001.

2. Tanabe LP, Kobayash RM. Profile, competencies and digital fluency of nurses in the Professional Improvement Program. Rev Esc Enferm USP [Internet]. 2013 [cited 2015 May 04];47(4):943-9. Available from: http://dx.doi.org/10.1590/S0080-623420130000400024

3. Gonçalves LS. Competências em informática requeridas de enfermeiros na prática profissional brasileira. 2013. [Tese]. Curitiba: Departamento de Enfermagem, Universidade Federal do Paraná; 2013.

4. Behar PA. Modelos Pedagógicos em Educação à Distância. [Internet]. 2009 [cited 2015 Aug 18]. Available from: http://www. nuted.ufrgs.br/oa/arqueads/apoio/modelospedagogicos.pdf

5. Associação Brasileira de Educação a Distância (ABED). Censo EAD.BR: relatório analítico da aprendizagem a distância no Brasil. Curitiba: Ibpex; 2012.168 p.

6. Freitas Junior NI, Freitas NMC. Objetos de aprendizagem para o ensino da história: uma busca na web. Rev Lat-Am Hist[Internet]. 2013 [cited 2015 Oct 09];2(6):752-66. Available from: http://projeto.unisinos.br/rla/index.php/rla/article/viewFile/232/185

7. Speroni KS, Vizzott JK. Recursos midiáticos na educação à distância em enfermagem: uma revisão narrativa da literatura. Rev VIDYA[Internet]. 2015 [cited 2015 Oct 24];35(1):41-56. Available from: http://www.periodicos.unifra.br/index.php/VIDYA/article/ view/230/217

8. Johnson L, Adams Becker S, Cummins M, Estrada V. 2014 NMC Technology Outlook for Brazilian Universities: a horizon project regional report. Austin, Texas: The New Media Consortium; Saraiva, 2014.

9. Freeman A, Adams Becker S, Hall C. 2015 NMC Technology Outlook for Brazilian Universities: A Horizon Project Regional Report. Austin, Texas: The New Media Consortium; Saraiva, 2015.

10. Netto M. Aprendizagem na EaD, mundo digital e 'gamification'. In: Fadel LM, Ulbricht VR, Batista CR, Vanzin T, (Org.). Gamificação na educação. São Paulo: Pimenta Cultural; 2014. p.98-121.

11. Quadros GBF. Construindo o estado da arte da gamificação. In: XII Encontro Virtual de Documentação em Software Livre (EVIDOSOL) e IX Congresso Internacional de Linguagem e Tecnologia (CILTEC). Anais do XIII Evidosol e X Ciltec-online; 2016 Jun; Minas Gerais: 2016.

12. Bunchball I. Gamification 101: an introduction to the use of game dynamics to influence Behavior. 2010. [cited 2015 Jul 06]. Available from: http://www.bunchball.com/sites/default/files/downloads/gamification101.pdf

13. Deterding S, Björk S, Nacke LE, Dixon D, Lawley E. Designing gamification: creating gameful and play ful experiences. In: Conference on Human Factors in Computing Systems, 2013, Paris, França. Proceedings. Paris, 2013[cited 2014 Oct 14]. p.1-4 Available from: http://lawley.rit.edu/wordpress/wp-content/uploads/2014/02/DesigningGamification.pdf

14. Araújo I. Gamification: metodologia para envolver e motivar alunos no processo de aprendizagem. Educ Knowl Soc[Internet]. 2016 [cited 2016 Oct 01];17(1):87-107. Available from: https://www.researchgate.net/profile/Ines_Araujo4/publication/303463794_Gamification_ metodologia para envolver y motivar alumnos en el proceso de aprendizaje/links/576838b708ae8ec97a4242ae.pdf

15. Klock ACT, Carvalho MF, Rosa BE, Gasparini I. Análise das técnicas de Gamificação em Ambientes Virtuais de Aprendizagem. Rev Renote [Internet] 2014 [cited 2016 May 29];12(2):1-10. Available from: http://seer.ufrgs.br/index.php/renote/article/ view/53496/33013

16. Quast K. Gamificando uma disciplina de Pós-Graduação em Linguística Aplicada. Rev Cam Ling Apl [Internet]. 2016 [cited 2016 Oct 10];14(1):183-209. Available from: http://revistas.unitau.br/ojs-2.2/index.php/caminhoslinguistica/article/viewFile/2159/1564 
17. Martins RS, Fernandes KT. Gamificação como Fator Motivacional para Diminuição das Taxas de Evasão nos MOOC. In: Nunes ID, Maia DL. Congresso Regional sobre Tecnologias na Educação (Ctrl +e 2016). Anais do Congresso Regional sobre Tecnologias na Educação; 2016 May. Natal: 2016, p.200-9.

18. Tenório T, Silva AR, Tenório A. A influência da gamificação na Educação a Distância com base nas percepções de pesquisadores brasileiros. Revista EDaPECI São Cristóvão (SE). [Internet]. 2016 [cited 2016 May 28];16(2):320-35. Available from: http://www. seer.ufs.br/index.php/edapeci/article/view/4554/pdf

19. Brasil. Ministério da Saúde. Conselho Nacional de Saúde (CNS). Resolução CNS Nº 466, de 12 de dezembro de 2012.

20. Castro TC, Gonçalves, LS. Informática em Enfermagem: uma proposta de curso baseada em competências. Rev Saúde Dig Tec Educ[Internet]. 2017 [cited 2017 Apr 20]. Available from: http://resdite.nuteds.ufc.br/index.php/revista/article/view/27/37

21. Kuntz VH. Critérios de design e ergonomia para avaliação de conteúdo informacional voltado para auto-aprendizagem. [Dissertação]. Curitiba: Departamento de Ciência e Gestão da Informação, Universidade Federal do Paraná; 2007.

22. Bardin L. Análise de Conteúdo. 20th ed. Lisboa: Edições 70; 2011.

23. Marope PTM, Chakroun B, Holmes KP. Liberar o potencial: transformar a educação e a formação técnica e profissional. Brasília: Unesco, 2015. 232p.

24. Vieira MA, Souto LES, Souza SM, Lima CA, Ohara CVS, Domenico EBL. Diretrizes Curriculares Nacionais para a área da enfermagem: o papel das competências na formação do enfermeiro. Rev Norte Min Enferm [Internet]. 2016 [cited 2016 Oct 06];5(1):105-21. Available from: http://www.renome.unimontes.br/index.php/renome/article/viewFile/102/148

25. Salvador ME, Sakumoto M, Marin HF. Uso do Moodle na Disciplina de Informática em Enfermagem. J Health Inform[Internet]. 2013[cited 2016 Oct 20];5(4):121-6. Available from: http://www.jhi-sbis.saude.ws/ojs-jhi/index.php/jhi-sbis/article/view/268/181

26. Costa ACS. Gamificação, elementos de jogos e estratégia: uma matriz de referência. 2014. [Monografia]. Curitiba: Departamento de Ciência e Gestão da Informação, Universidade Federal do Paraná; 2014.

27. Prado C, Vaz DR, Almeida DM. Teoria da Aprendizagem Significativa: elaboração e validação de aula virtual na plataforma Moodle. Rev Bras Enferm[Internet] 2011[cited 2015 Oct 05];54(6):1114-21. Available from: http://dx.doi.org/10.1590/S0034-71672011000600019

28. Fonseca LMM, Aredes NDA, Leite AM, Santos CB, Lima RAG, Scochi CGS. Evaluation of an educational technology regarding clinical evaluation of preterm newborns. Rev Latino-Am Enfermagem [Internet]. 2013 [cited 2015 Oct 05];21(1). Available from: http://dx.doi.org/10.1590/S0104-11692013000100011

29. Mori S, Whitaker IY, Marin HF. Evaluation of an educational website on First Aid. Rev Esc Enferm USP [Internet]. 2013 [cited 2015 Oct 05];47(4):950-7. Available from: http://dx.doi.org/10.1590/S0080-623420130000400025

30. Lima MA, Pagliuca LMF, Nascimento JC, Caetano JA. Virtual guide on ocular self-examination to support the self-care practice for people with HIV/AIDS. Rev Esc Enferm USP [Internet]. 2014 [cited 2015 Oct 05];48(2):285-91. Available from: http://dx.doi. org/10.1590/S0080-6234201400002000013

31. Silva KL, Évora YDM, Cintra CSJ. Software development to support decision making in the selection of nursing diagnoses and interventions for children and adolescents. Rev Latino-Am Enfermagem [Internet];2015[cited 2016 Oct 10];23(5):927-35. Available from: http://dx.doi.org/10.1590/0104-1169.0302.2633

32. Bissolotti K, Nogueira HG, Pereira ATC. Potencialidades das mídias sociais e da gamificação na educação a distância. Rev Renote [Internet]. 2014 [cited 2016 Oct 17];12(2):1-11. Available from: http://seer.ufrgs.br/index.php/renote/article/view/53511/33027

33. Frota NM. Comparação de estratégias de ensino: aula expositiva dialogada e hipermídia educativa sobre punção venosa periférica [Tese]. Fortaleza: Departamento de Enfermagem, Universidade Federal do Ceará; 2016. 